Article

\title{
Immunolocalization of Keratan Sulfate in Rat Spinal Tissues Using the Keratanase Generated BKS-1(+) Neoepitope: Correlation of Expression Patterns with the Class II SLRPs, Lumican and Keratocan
}

\author{
Anthony J. Hayes ${ }^{1}$ and James Melrose ${ }^{2,3,4, *(\mathbb{D}}$ \\ 1 Bioimaging Research Hub, Cardiff School of Biosciences, Cardiff University, Cardiff CF10 3AX, Wales, UK; \\ HayesAJ@cardiff.ac.uk \\ 2 Graduate School of Biomedical Engineering, University of New South Wales, Sydney, NSW 2052, Australia \\ 3 Raymond Purves Laboratory, Institute of Bone and Joint Research, Kolling Institute of Medical Research, \\ Northern Sydney Local Health District, Faculty of Medicine and Health, University of Sydney Royal North \\ Shore Hospital, St. Leonards, NSW 2065, Australia \\ 4 Sydney Medical School, Northern, University of Sydney at Royal North Shore Hospital, \\ St. Leonards, NSW 2065, Australia \\ * Correspondence: james.melrose@sydney.edu.au
}

Received: 8 February 2020; Accepted: 28 March 2020; Published: 30 March 2020

check for updates

\begin{abstract}
This study has identified keratan sulfate in fetal and adult rat spinal cord and vertebral connective tissues using the antibody BKS-1(+) which recognizes a reducing terminal $\mathrm{N}$-acetyl glucosamine-6-sulfate neo-epitope exposed by keratanase-I digestion. Labeling patterns were correlated with those of lumican and keratocan using core protein antibodies to these small leucine rich proteoglycan species. BKS-1(+) was not immunolocalized in fetal spinal cord but was apparent in adult cord and was also prominently immunolocalized to the nucleus pulposus and inner annulus fibrosus of the intervertebral disc. Interestingly, BKS-1(+) was also strongly associated with vertebral body ossification centers of the fetal spine. Immunolocalization of lumican and keratocan was faint within the vertebral body rudiments of the fetus and did not correlate with the BKS-1(+) localization indicating that this reactivity was due to another KS-proteoglycan, possibly osteoadherin (osteomodulin) which has known roles in endochondral ossification. Western blotting of adult rat spinal cord and intervertebral discs to identify proteoglycan core protein species decorated with the BKS-1(+) motif confirmed the identity of 37 and $51 \mathrm{kDa}$ BKS-1(+) positive core protein species. Lumican and keratocan contain low sulfation KS-I glycoforms which have neuroregulatory and matrix organizational properties through their growth factor and morphogen interactive profiles and ability to influence neural cell migration. Furthermore, KS has interactive capability with a diverse range of neuroregulatory proteins that promote neural proliferation and direct neural pathway development, illustrating key roles for keratocan and lumican in spinal cord development.
\end{abstract}

Keywords: keratan sulfate; keratocan; lumican; intervertebral disc; spinal cord; endochondral ossification; neural development

\section{Introduction}

Keratan sulfate (KS) is a widely distributed glycosaminoglycan (GAG) component of proteoglycans (PGs) in the extracellular matrix (ECM) and on cell surfaces of tensional and weight-bearing connective tissues such as ligaments, tendons, articular cartilage, and intervertebral discs (IVD), in addition to corneas and the central and peripheral nervous systems (CNS/PNS) [1-3]. Historically, most of the 
information on the spatio-temporal distribution and function of KS-PGs has been gleaned through the use of the monoclonal antibody (MAb) 5-D-4 which detects disulfated heptasaccharide regions of high charge density in KS chains [4]. KS is initially synthesized as a polylactosamine chain sulfated on its GlcNAc residues in a monosulfated KS glycoform [5], and with tissue maturation galactose residues of the GlcNAc-Gal KS repeat disaccharide become progressively sulfated at C6 leading to regions of disulfation on the KS chains. KS is heterogeneous and contains variably distributed regions which are non-sulfated, and mono- and disulfated [1]. While heptasaccharide groupings of disulfated regions on KS are detected by MAb 5-D-4, this antibody provides no information on mono-or non-sulfated regions of KS [6]. As MAb 5-D-4 is incapable of detecting low charge density KS species, its application to embryonic and fetal connective tissues may under represent the quantity and distribution of KS GAGs which have yet to develop appreciable levels of highly sulfated KS epitopes. Antibodies to the mono-sulfated (MAb R10-G, 1B4) [7] and non-sulfated polylactosamine regions of KS (MAb ' $i$ ') [8] are now available and, in combination with specific KS depolymerizing enzymes, functional roles for these regions are now emerging [9]. BKS-1 immunolocalization is therefore a more accurate quantitative measure of KS since one BKS-1 epitope is labeled per KS chain in all KS glycoforms irrespective of their charge status (Figure 1).

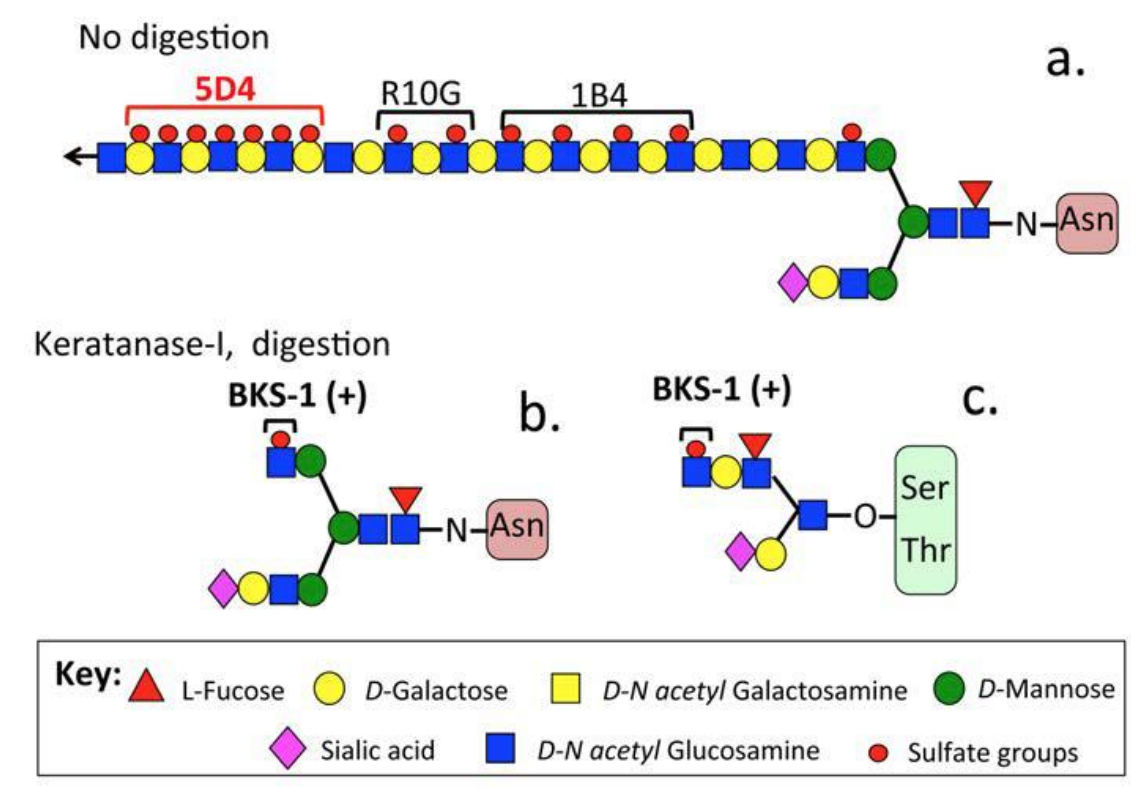

Figure 1. Structure of a typical KS-I chain and identification of high charge density 5-D-4 and low charge density R10G and 1-B-4 antibody binding sites (a) in N- (b) and O-linked KS chains (c).

MAb BKS-1 identifies KS in early tissue development in KS-PGs containing low sulfation KS glycoforms as well as highly sulfated KS in mature tissues. In corneal tissues, MAb 5-D-4 and BKS-1 detect similar corneal KS-PG populations by Western blotting [10] and, in immunolocalizations, BKS-1 displays a more subtle localization of KS than 5-D-4 [11], possibly due to the stoichiometry of 5-D-4 and BKS-1 antibody binding to KS chains. BKS-1 staining is quantitative, thus the relative levels of $\mathrm{KS}$ in different regions of a given tissue can be precisely compared. Furthermore, whereas MAb 5-D-4 detects longer, more highly sulfated KS chains, BKS-1 detects shorter, less highly sulfated KS chains, typical of those found in lumican, keratocan, and proline/arginine-rich end leucine-rich repeat protein (PRELP) in fetal or embryonic tissues. The presence of these low sulfation KS glycoforms has previously been under-appreciated [1]. For example, a mono-sulfated KS glycoform in electro-sensory tissues of the Ampullae of Lorenzini in elasmobranch sharks and rays is the sole GAG found in these tissues [12] and is the most sensitive proton detection agent known in nature [13]. A natural killer (NK) cell-restricted KS-glycoprotein (PEN5), a developmentally-regulated post-translational modification of the platelet selectin glycoprotein ligand-1 (PSGL-1), is a unique binding site for L-selectin expressed 
by platelets, endothelial cells, and leukocytes serving as a functional NK-homing-trafficking receptor delivery system and a molecular switch in the activation of cytolytic NK cells in the innate immune response [14]. KS is also a functional cell surface component of the glycocalyx in human embryonic stem cells with specific roles in their differentiation into defined cell lineages [15].

A recent study with corneal KS also showed that this GAG interacted with a diverse range of morphogens, growth factors, nerve growth factor receptors, and members of the Robo, Slit, Ephrin, Ephrin receptor, and Semaphorin families of neuroregulatory proteins [16]. The strong localization of BKS-1(+) KS observed in the spinal cord (SC) of adult rats in the present study is consistent with roles for KS in neuroregulation and neural guidance in the CNS/PNS [3] and provides further evidence that low sulfation KS glycoforms may have novel functional roles in the growth and development of the SC and vertebral column.

\section{Materials and Methods}

All materials and supplier details were as specified earlier [17].

\subsection{Tissues}

Human cartilage was donated by total knee replacement patients using the North Sydney Area Health Authority Ethics protocol 0404-103M (Oct 2004-2008): J Melrose, C Little, D Sonnabend"Pathobiology of the small leucine rich repeat proteoglycans in cartilage, intervertebral disc and tendon degeneration" which covers the use of human tissues discarded at surgery. Late fetal (embryonic days 19-20) and adult (4 month) spinal tissues from white Wistar rats were used in this study as described previously [18]. These were killed humanely using a Schedule 1 procedure (Animals Scientific Procedures Act, 1986, UK).

\subsection{Antibodies}

The LUM-1 and KER-1 core protein antibodies used in this study (Table 1) have been described previously $[17,18]$ as has the BKS-1(+) KS stub neoepitope antibody [11,19] (Figure 1). Please note that the KS antibodies used in the present study detect sulfated epitopes in the KS and should not be confused with anti-aminoacyl-tRNA synthetase antibodies which have also been referred to as KS antibodies [20] or the anti-cyclin D1/D2 5-D-4 antibody [21].

The LUM-1 and KER-1 monoclonal antibodies used in this study were kind gifts from Dr Briedgeen Kerr prepared as part of her PhD studies, Keratan Sulfate Metabolism in Connective Tissue Proteoglycans conducted at The University of Cardiff, UK (2005). The authenticity of these antibodies was determined using extracts of human knee articular cartilage which contains lumican and keratocan [17]. Human recombinant lumican and keratocan proteins produced in Escherichia coli and HEK 293T cells were purchased from OriGene (OriGene Technologies, Inc., Rockville, MD 2085, USA) and used as positive control standards in Western blots. A rabbit polyclonal antibody to keratocan (KTN, cat \# ab113115) raised to C-terminal amino acids 227-257 was also obtained from abcam (Cambridge, UK). A rabbit monoclonal Lumican antibody (B9, cat \# sc-166871) was obtained from Santa Cruz Biotechnology (Texas, USA). A rabbit polyclonal lumican antibody (PR-353) to the C-terminal amino acid sequence LRVANEVTLN was a gift from Prof Peter Roughley, McGill University, Canada. The KTN, B-9, and PR-353 antibodies were used in Western blotting with human knee cartilage extract or recombinant lumican and keratocan proteins to confirm that KER-1 and LUM-1 identified keratocan and lumican core proteins as shown previously in a number of studies $[5,17,22-25]$. 
Table 1. Keratocan and lumican antibodies used in this study.

\begin{tabular}{|c|c|c|c|}
\hline $\begin{array}{c}\text { Antibody, Ab Class } \\
\text { (Immunizing Antigen Used) }\end{array}$ & Source & Specificity & Reference \\
\hline $\begin{array}{l}\text { LUM-1, Mouse IgG monoclonal } \\
\text { (lumican core protein) }\end{array}$ & $\begin{array}{l}\text { Bridgeen Kerr, } \\
\text { Cardiff University, UK }\end{array}$ & $\begin{array}{l}\text { Mouse monoclonal IgG to } \\
51 \mathrm{kDa} \text { core protein }\end{array}$ & [26] \\
\hline $\begin{array}{l}\text { KER-1, Mouse IgG monoclonal } \\
\text { (keratocan core protein) }\end{array}$ & $\begin{array}{l}\text { Bridgeen Kerr, } \\
\text { Cardiff University, UK }\end{array}$ & $\begin{array}{l}\text { Mouse monoclonal IgG to } \\
38 \mathrm{kDa} \text { core protein }\end{array}$ & [26] \\
\hline $\begin{array}{l}\text { PR 353, Rabbit polyclonal } \\
\text { (lumican C-terminal peptide } \\
\text { LRVANEVTLN) }\end{array}$ & $\begin{array}{l}\text { Peter Roughley, } \\
\text { McGill University, Canada }\end{array}$ & $\begin{array}{l}\text { Rabbit polyclonal Ab identifies } \\
\text { LRVANEVTLN } \\
\text { C-terminal peptide in lumican species }\end{array}$ & [17] \\
\hline $\begin{array}{l}\text { KTN, Rabbit polyclonal Ab, } \\
\text { (C-terminal amino acids 227-257 } \\
\text { of keratocan) }\end{array}$ & Abcam (cat \# ab113115), UK & $\begin{array}{l}\text { Rabbit polyclonal } \mathrm{Ab} \text { to } 38 \mathrm{kDa} \\
\text { keratocan core protein }\end{array}$ & [27] \\
\hline $\begin{array}{l}\text { B9 Mouse monoclonal IgG } \\
\text { (lumican core protein) }\end{array}$ & Santa Cruz (cat \# sc-166871), USA & $\begin{array}{l}\text { Rabbit monoclonal to } 51 \mathrm{kDa} \\
\text { clumican ore protein }\end{array}$ & {$[28,29]$} \\
\hline $\begin{array}{l}\text { BKS-1(+) Mouse monoclonal IgG } \\
\text { (keratanase digested KS) }\end{array}$ & $\begin{array}{l}\text { Bridgeen Kerr, } \\
\text { Cardiff University, UK }\end{array}$ & $\begin{array}{l}\text { Galactosamine-6-sulfate-galactose } \\
\text { disaccharide in KS linkage region }\end{array}$ & [26] \\
\hline
\end{tabular}

\subsection{Histology}

Tissues were fixed in $10 \% w / v$ neutral buffered formol saline, decalcified in $2 \% v / v$ nitric acid until radiologically clear, and then processed into paraffin wax using standard histological methods. Serial sections were cut through the paraffin blocks containing embedded vertebral body/intervertebral disc segments in the sagittal plane and $6 \mu \mathrm{m}$ sections were collected onto Histobond glass histology slides (R.A. Lamb, UK/Thermo Fisher, www.thermofisher.com).

\subsection{Immunohistochemistry}

Tissue sections were de-waxed then rehydrated in sequential washes of xylene and graded ethanol to water and digested with a mixture of chondroitinase $\mathrm{ABC}(0.025 \mathrm{U} / \mathrm{mL})$ and keratanase- $\mathrm{I}(0.4 \mathrm{U} / \mathrm{mL})$ in $50 \mathrm{mM}$ Tris- $\mathrm{HCl} \mathrm{pH} 6.50 .1 \mathrm{M} \mathrm{NaCl}$ for $3 \mathrm{~h}$ at $37^{\circ} \mathrm{C}$ before washing in phosphate buffered saline (PBS) $\mathrm{pH}$ 7.4. Endogenous peroxidase was initially blocked by incubation of the sections in $0.3 \% v / v$ hydrogen peroxide in water for $1 \mathrm{~h}$. After washing, non-specific protein binding in the sections was blocked with normal horse-serum for $30 \mathrm{~min}$. Primary antibodies KER-1, LUM-1, and BKS-1 were used at a 1:20 dilution $[11,19]$ and incubated overnight with tissue sections at $4{ }^{\circ} \mathrm{C}$. Controls sections were incubated with irrelevant naïve immunoglobulins of the same isotype or the primary antibody was omitted, being replaced with PBS, pH 7.4. All staining with immunoglobulin control samples were negative, showing no non-specific antibody labeling. Primary antibody localizations were visualized using the Vector $\mathrm{ABC}$ universal immunoperoxidase labeling kit (Vector Laboratories, Burlingame, $\mathrm{CA}$, USA) using NovaRed peroxidase substrate (Vector Laboratories). The sections were then washed, counterstained with haematoxylin, and mounted under coverslips with DPX mountant and imaged under brightfield optics using a Surveyor slide scanning system (Objective Imaging, Cambridge, UK) equipped with a QICAM Fast 1394 color CCD digital camera (Teledyne QImaging, Canada). BKS-1(+) sections required keratanase digestion to generate the BKS-1(+) epitope. Omission of the keratanase digestion step resulted in an absence of generation of the BKS-1(+) epitope.

Rat tissue sections were also stained with $0.05 \%$ alcian blue $8 \mathrm{GX}$ to visualize sulfated GAG, or immunolabeled with antibodies to type II and VI collagens $(1 \mu \mathrm{g} / \mathrm{mL})$ overnight at $4{ }^{\circ} \mathrm{C}$ as specified earlier [30] to provide tissue context within the spinal tissues.

\subsection{Extraction of PGs from Rat and Human Tissues}

Finely diced tissue from 12 rat IVDs from two 4 month old male Wister rats and SC from 2 rats were extracted in 10 volumes of $4 \mathrm{M} \mathrm{GuHCl} 0.5 \mathrm{M}$ sodium acetate $(\mathrm{pH} 5.8)$ containing $10 \mathrm{mmol} / \mathrm{L}$ EDTA, $20 \mathrm{mmol} / \mathrm{L}$ benzamidine, and $50 \mathrm{mmol} / \mathrm{L}$ 6-aminohexanoic acid for $48 \mathrm{~h}$ at $4{ }^{\circ} \mathrm{C}$. PGs were also extracted from surgically discarded total knee replacement human knee articular cartilage using $4 \mathrm{M}$ $\mathrm{GuHCl}$ for antibody validation studies. 


\subsection{Chondroitinase $A B C$ and Keratanase-I Digestion of Proteoglycan Samples}

Freeze dried tissue extracts were re-dissolved ( $2 \mathrm{mg}$ dry weight $/ \mathrm{mL})$ in $0.1 \mathrm{M}$ Tris $0.03 \mathrm{M}$ acetate buffer $(\mathrm{pH} 6.5)$, and aliquots $(0.5 \mathrm{~mL})$ were pre-digested with chondroitinase $A B C(0.1 \mathrm{U})$ and keratanase-I $(0.05 \mathrm{U})$ overnight at $37^{\circ} \mathrm{C}$.

\subsection{Lithium Dodecyl Sulfate PAGE and Western Blotting}

Chondroitinase ABC and keratanase-I digested PG samples $(0.1 \mathrm{~mL} ; 2 \mathrm{mg} / \mathrm{mL})$ were mixed with $4 \times$ lithium dodecyl sulfate PAGE application buffer $(35 \mu \mathrm{L})$ and $500 \mathrm{mM}$ dithiothreitol $(15 \mu \mathrm{L})$ heated at $70{ }^{\circ} \mathrm{C}$ for $30 \mathrm{~min}$, cooled, and $25 \mu \mathrm{L}$ aliquots electrophoresed under reducing conditions on $10 \%$ NuPAGE Bis-Tris gels at $200 \mathrm{~V}$ constant voltage for 50 min using NuPAGE MOPS (3- [N morpholino]-propanesulfonic acid) pH 7.0 SDS electrophoresis buffer. Gels were electroblotted to nitrocellulose membranes $(0.22 \mu \mathrm{m})$ in NuPAGE transfer buffer containing $10 \%$ methanol at $30 \mathrm{~V}$ constant voltage for $1 \mathrm{~h}$. SeeBlue-2 pre-stained protein molecular weight standards (InVitrogen Australia, Mount Waverley, Vic, Australia) were also electrophoresed. Blots were blocked for $3 \mathrm{~h}$ in $5 \%$ bovine serum albumin in $50 \mathrm{mM}$ Tris- $\mathrm{HCl} 0.15 \mathrm{M} \mathrm{NaCl}$ (pH 7.2; TBS) and anti-lumican, anti-keratocan, or anti-BKS-1 antibodies $(1 \mu \mathrm{g} / \mathrm{mL})$ added overnight in $2 \%$ bovine serum albumin in TBS. Goat anti-rabbit or anti-mouse IgG alkaline phosphatase conjugated secondary antibodies $(1 / 5000$ dilution) were added for $1 \mathrm{~h}$. The blots were then washed in TBS and developed with NBT/BCIP (nitro-blue tetrazolium chloride/5-bromo-4-chloro-3'-indolyphosphate) substrates in $0.1 \mathrm{M}$ Tris- $\mathrm{HCl}$ $\mathrm{pH} 9.5$ containing $5 \mathrm{mM} \mathrm{MgCl}_{2}$ for $20 \mathrm{~min}$ at room temperature.

\section{Results}

The schematic shown in Figure 1 summarizes the structural epitopes within the KS GAG chain structure that are identified by some of the most commonly used KS antibodies. BKS-1 detects a reducing terminal $\mathrm{N}$-acetyl glucosamine-6-sulfate neo-epitope exposed by keratanase-I digestion, i.e., $\mathrm{BKS1}(+)$. The (+) designation is used to signify that keratanase-I is required to expose this epitope.

\subsection{Western Blotting}

Western blotting of extracts of SC and IVD from adult (4 month) old rat spinal tissues showed that both tissues contained lumican and keratocan and BKS-1(+) positive KS-PGs (Figure 2a). Lumican and keratocan core proteins also contained the BKS-1(+) epitope (Figure 2a). The LUM-1 and KER-1 antibodies displayed similar KS-PG detection profiles to those detected by the B-9 and PR-353 anti-lumican and KTN anti-keratocan antibodies in human articular cartilage tissue extracts (Figure $3 \mathrm{~b}$ ) and to recombinant $51 \mathrm{kDa}$ lumican and $37 \mathrm{kDa}$ keratocan core protein standards (Figure 3c). The BKS-1(+) positive lumican and keratocan PG core protein species detected in the present study demonstrate that these PGs contain low sulfation KS glycoforms in embryonic and neonatal spinal cord while highly charged 5-D-4 positive KS chains are also known to be present on these PGs in mature and in pathological connective tissues. 


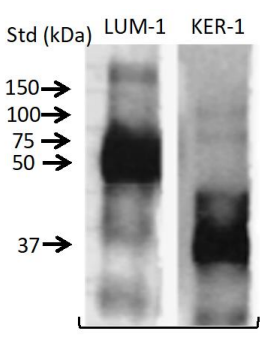

Cord

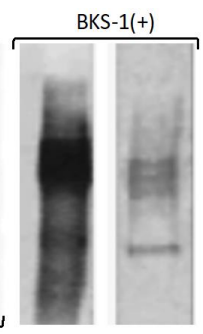

IVD Cord

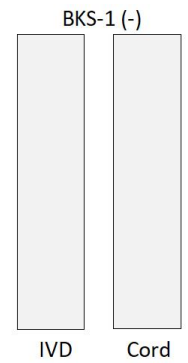

a.

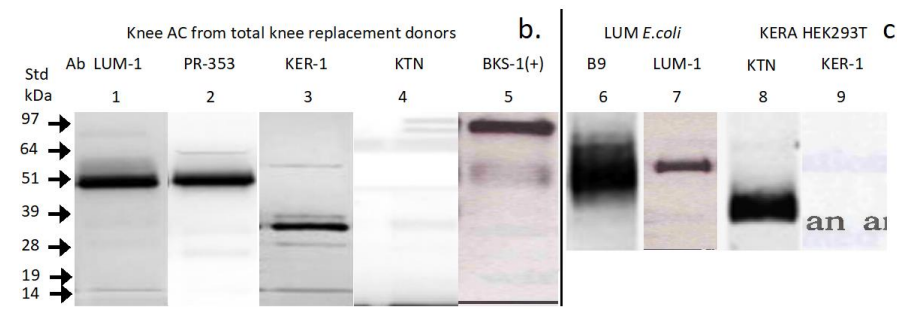

Figure 2. Western blotting validation of the specificity of the KER-1 and LUM-1 antibodies and comparison of the KS species identified by BKS-1 with keratanase pre-digestion (+) or without keratanase digestion (-) in extracts of 4 month rat spinal tissues (a), human articular cartilage, (b) and positive identification of recombinant lumican (LUM E. coli) and keratocan (KERA HEK 293T) standard proteins (c). The PG species detected in extracts of human articular cartilage (AC) by a number of commercial and gifted lumican (PR-353; B9, Santa Cruz cat \# sc-166871) and keratocan (KTN, abcam cat \# ab113115) were also compared with those identified by LUM-1 and KER-1 (b). All samples were predigested with keratanase-I.
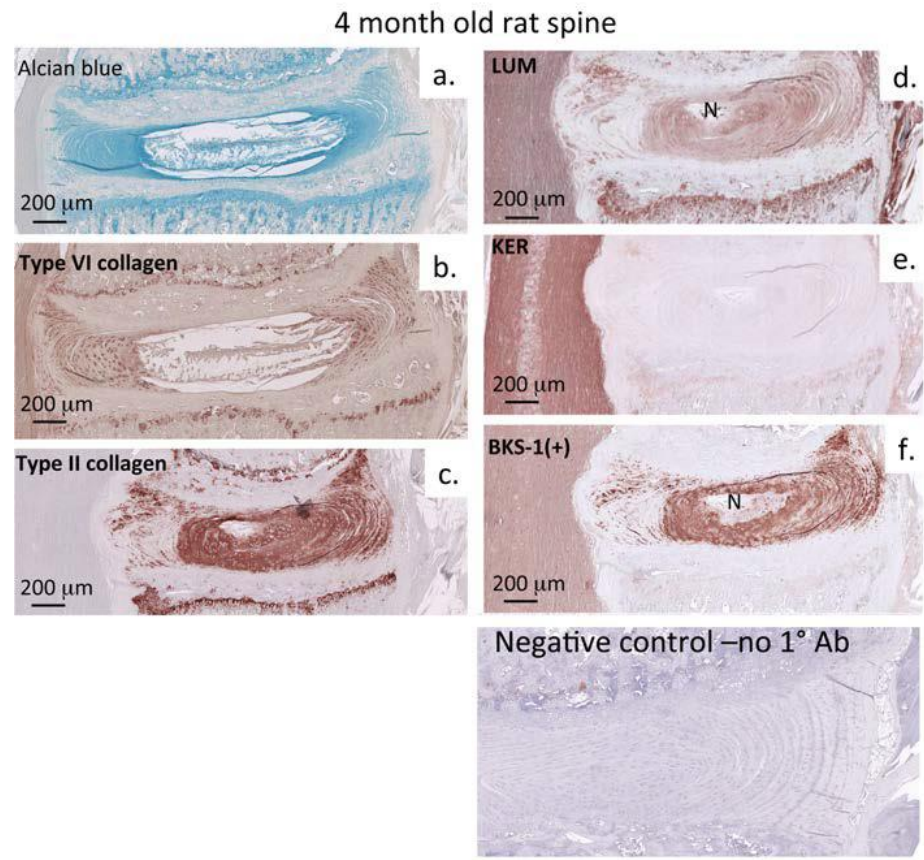

Figure 3. Visualization of the distribution of rat spinal components. Histochemistry/ immunohistochemistry of alcian blue proteoglycan (a), type VI collagen (b), type II collagen (c), lumican (d), keratocan (e), and BKS-I $(+)(f)$ in a 4 month old rat spinal segment. Alcian blue and antibodies towards collagen types II and VI have been used to delineate the constituent spinal connective tissues. Lumican is immunolocalized to the nucleus pulposus and inner annulus fibrosus and prominently in the vertebral growth plate cartilages and anterior longitudinal ligament, however keratocan is only weakly immunolocalized to the vertebral growth plate. BKS-1(+) epitope is prominently immunolocalized in the nucleus pulposus, inner annulus fibrosus, and the vertebral growth plates. 


\subsection{Immunohistochemistry: Adult Rat Spinal Tissue}

At 4 months the rat vertebral column was skeletally mature and its associated connective tissues had fully formed. Alcian blue staining for sulfated GAG (Figure 2a) and IHC for collagen types II and VI (Figure 3b,c) were used to delineate the constituent musculoskeletal tissues, highlighting the positions of the vertebral growth plates (GP), the cartilage end plates (CEP), the NP and AF of the IVD, and adjacent SC tissue. Immunohistochemistry of adult (4 month) rat spinal tissues showed that BKS-1(+), lumican, and keratocan were all identifiable within the SC ECM, IVD, and GP (Figures 3d-f and $4 \mathrm{a}-\mathrm{c})$. Lumican was prominently immunolocalized to the GP using the LUM-1 core protein Ab (Figure 3d) but not with BKS-1(+) (Figure 3f) suggesting that the form of lumican in the GP may be unsulfated; further studies need to be undertaken to confirm this observation. Higher magnifications of the SC tissue showed that BKS-1(+) was broadly localized throughout the ECM and associated with glial cells and neurons, but not astrocytes (Figure 4d). This contrasted with the fetal rat SC tissue in which the BKS-1(+) epitope could not be detected (Figure 5a).

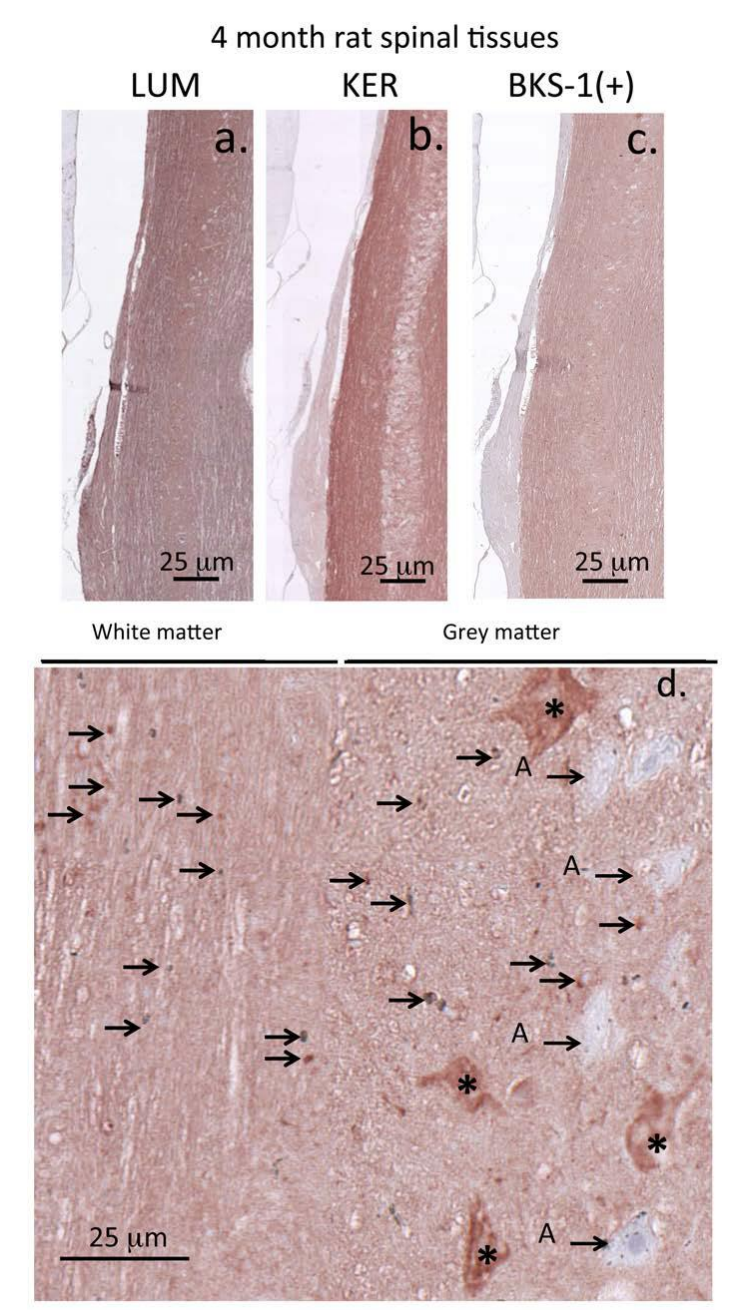

Figure 4. Immunolocalization of keratocan (a), lumican (b), and BKS-1 (+) KS neo-epitope (c) in 4 month old rat spinal tissue shows them to be widely distributed throughout the spinal cord. A higher power image of BKS-1(+) shows reactivity prominently localized throughout the spinal cord extracellular matrix and also labeled glial cells and neurons. (d) Glial cells are arrowed and motor neurons labeled with an asterisk, astrocytes (A) are labeled with a small arrow. Scale bars $100 \mu \mathrm{m}$. Chromogen NovaRED. 
BKS-1(+) LUM KER

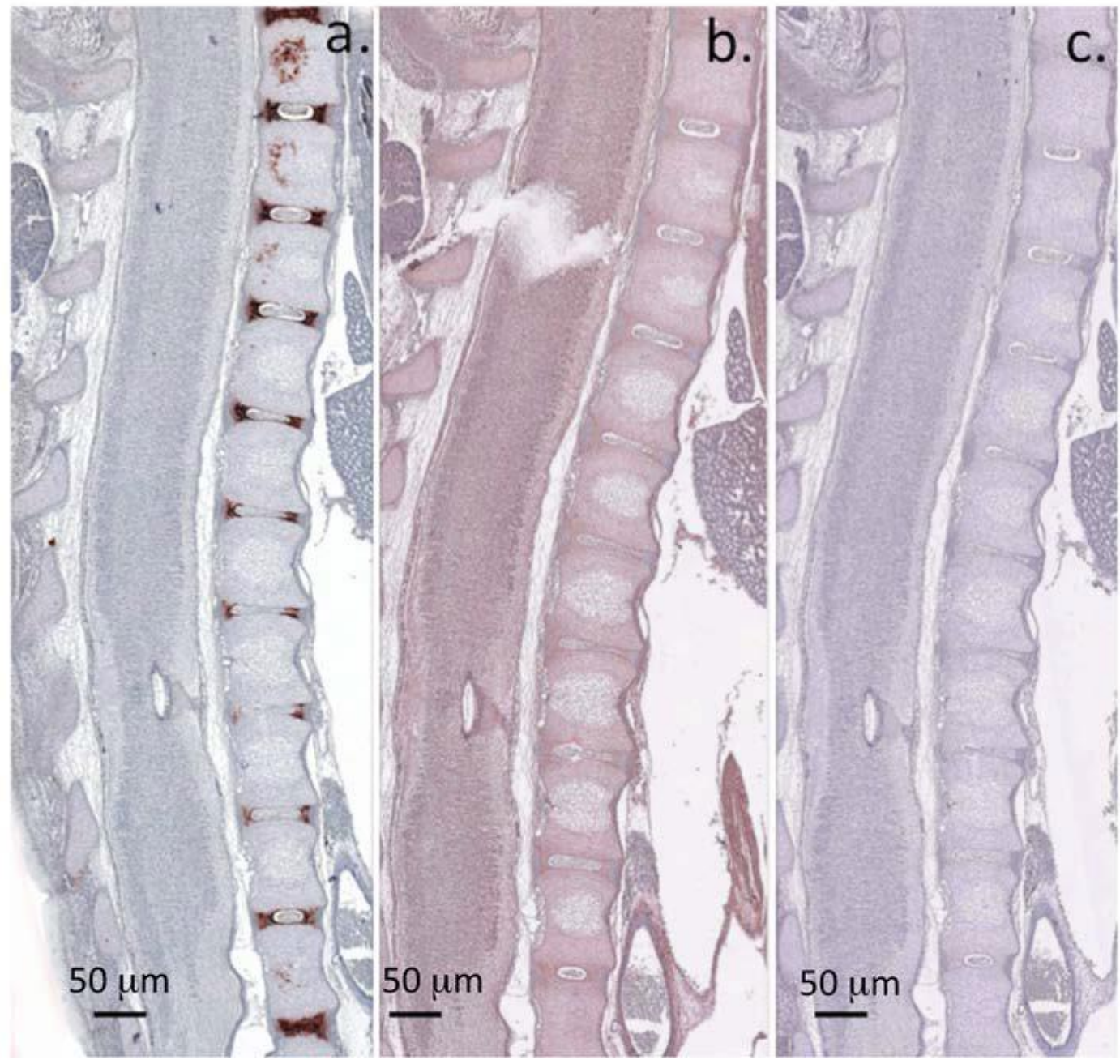

Figure 5. Macroscopic longitudinal sections depicting the immunolocalization of BKS-1(+) KS neoepitope in chondroitinase $\mathrm{ABC}$, keratanase I-digested spinal tissue sections (a), lumican (b), and Keratocan (c). BKS-1(+) reactivity is evident in the pre-ossification centers in the vertebral bodies, and the cartilaginous inner annulus fibrosus of the developing intervertebral discs (a). BKS-1 (+) is also immunolocalized to the notochordal sheath surrounding notochordal remnants in the central intervertebral disc at some levels but not in the notochord itself which has been lost by this stage. Staining for BKS-1 (+) epitope is negative in the spinal cord at this stage of spinal development and only weak for lumican. Scale bars $100 \mu \mathrm{m}$. NovaRED chromogen.

\subsection{Immunohistochemistry: Fetal Rat Spinal Tissue}

Immunolocalization studies of late fetal rat spinal tissues with BKS-1(+) showed strong ECM labeling of keratanase-generated KS neoepitopes within the cartilaginous inner AF of the developing IVD (Figure 5a). Labeling was also present within the notochordal sheath surrounding the NP but was absent from the notochordal remnant tissue within the nascent NP. Strong labeling was also noted within the pre-ossification centers of the vertebral rudiments (particularly prominent rostrally in the section plane shown). However, there was a conspicuous absence of BKS-1(+) labeling within the fetal SC tissue (Figures 5a and 6a). In contrast, lumican (Figure 5b) was weakly detected within the fetal SC and vertebral cartilages, but was absent from their pre-ossification centers. Keratocan labeling (Figure $5 c$ ) was more restricted in its distribution and associated with only small numbers of cells within the developing SC 
and transitional tissue of the IVD. It was also absent from the vertebral pre-ossification centers; however, it was prominent within the stratum basale of the dermis (data not shown).
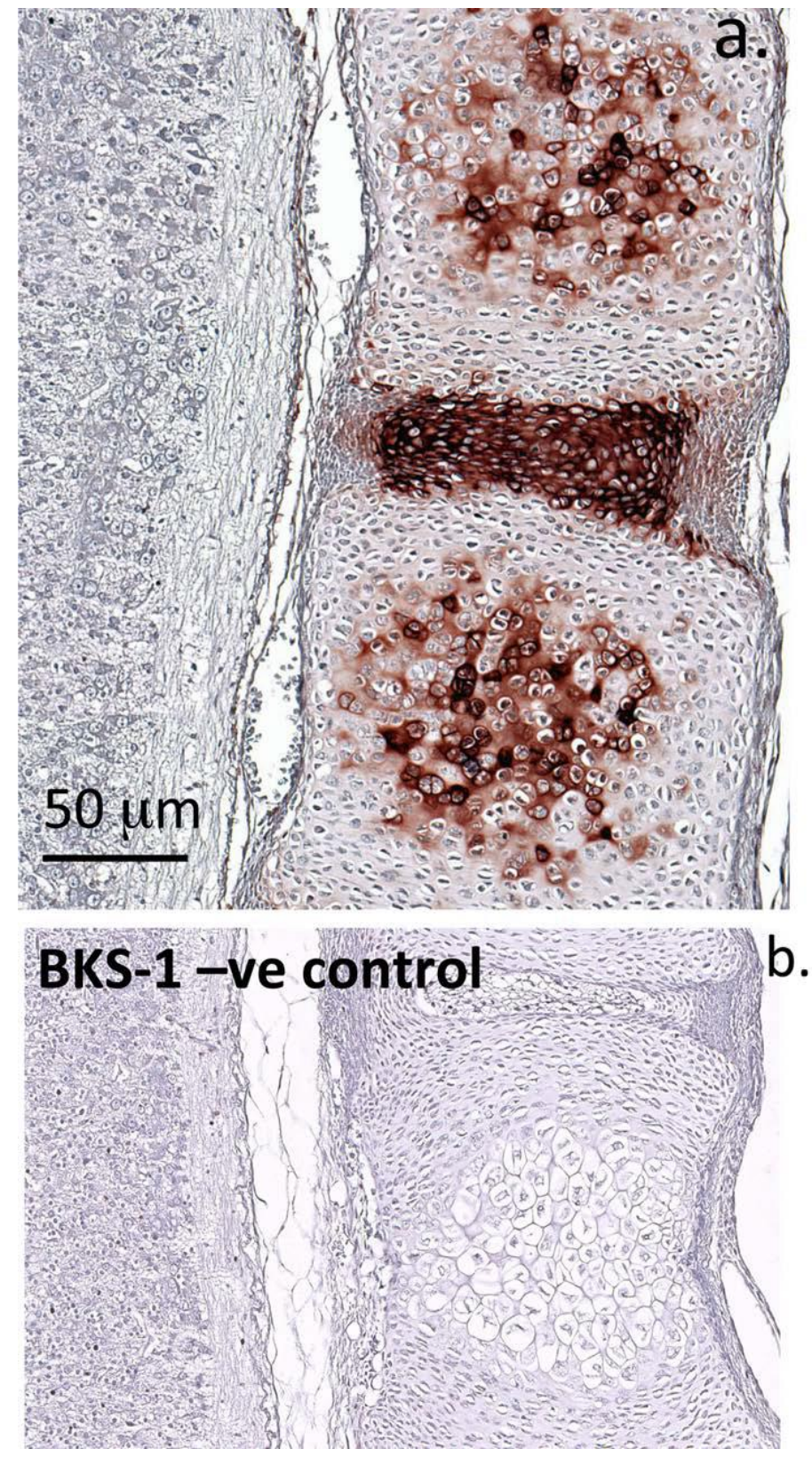

Figure 6. Immunolocalization of BKS-I(+) (a) in a late fetal rat spinal segment showing its localization in the pre-ossification centre within the vertebral body rudiment, and the cartilaginous inner annulus fibrosus of the disc. Note that the nucleus pulposus is outside the section plane of this parasagittal tissue slice taken through the disc. Chromogen used was novaRED. A negative control image is presented in (b).

Labeling of BKS-1(+) was highly prominent within the NP and AF of the IVD; however, it was not detected in the CEPs or adjacent GPs (Figure 6a). Lumican had a similar distribution to BKS-1(+), occurring within the NP and AF. It too was absent from the CEPs; however, unlike BKS-1(+) it was prominent in the vertebral GPs and the posterior longitudinal ligament (Figure 6a). Keratocan, whilst immunolocalizing strongly with the SC tissue was conspicuously absent from the adjacent IVD tissue and thus served as a negative control for the BKS-1 localizations (Figure 6b) 
Keratocan and lumican both have documented roles in the regulation of nerve migration during the development of the CNS/PNS. Figure 7 shows the distribution of blood vessels and encircling nerves in the E7 quail eye in regions known to be regulated by keratocan (Figure 7a). Lumican also regulates endothelial cell migration and blood vessel development and the formation of regular orthogonally arranged fine collagen fibers in the cornea essential for optimal clarity. Thus keratocan and lumican both have important roles in the development of the quail eye and ECM components in general. A diagrammatic representation of lumican and its structural organization important for its functional properties is shown (Figure $7 \mathrm{~b}$ ), and central leucine rich repeats (LRRs) and lumicans interactive regions with type I collagen are depicted. The lumcorin LRR9 and C-terminal lumikine ALK5/TGFBR1 binding peptide are also shown (Figure 7b).

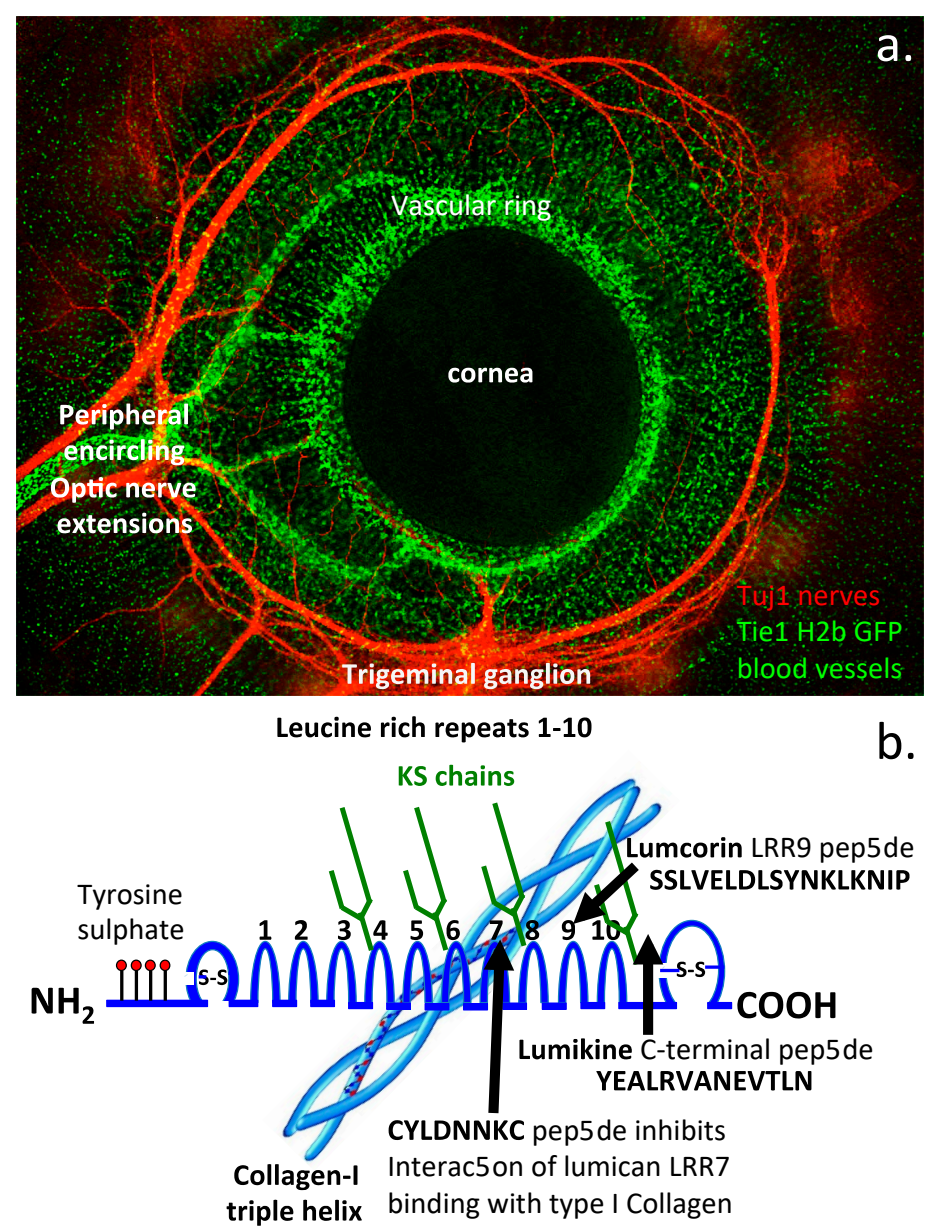

Figure 7. Composite figure depicting the distribution of nerves and blood vessels around the cornea in an embryonic quail and illustration of the structural organization of lumican which contributes to its functional properties in tissues. A fluorescent image depicts the developmental peripheral trigeminal nerve and associated blood vessels regulated by keratocan and lumican in the E7 quail eye. The trigeminal nerve was visualized using a Tuj-1 antibody. Ocular blood vessels were visualized using green fluorescent protein labeled TG-Tie-1H2b under the direction of the endothelial orphan receptor Tie-1 and plasminogen receptor histone 2B promoters. Image kindly supplied by Associate Prof Peter Ligwale, Rice University, USA (a). Diagrammatic depiction of lumicans structure and the leucine rich repeat 7 mediated interaction of lumican with type I collagen which regulates collagen fibrillogenesis (b). The synthetic peptide CYLDNNKC inhibits this interaction between lumican LRR7 and type-I collagen. A peptide, lumcorin from LRR9 also has $\alpha 2 \beta 1$ integrin binding and cell regulatory properties. Lumikine a C-terminal lumican peptide also binds ALK5/TGF $\beta R 1$ and has wound healing properties. 


\section{Discussion}

BKS-1(+) members of the small leucine rich proteoglycan (SLRP) family, including lumican and keratocan, have previously been reported in the development of the annulus fibrosus of the rat IVD [18]. In the present study we report on their wider distribution in rat spinal development using IHC and SDS-PAGE and Western blotting. We show that BKS-1(+), lumican, and keratocan have interesting spatio-temporal tissue-specific distributions that suggest they play complex roles in the development of the spinal cord and many of the constituent musculoskeletal connective tissues of the vertebral column. The BKS-1(+) reactivity observed within the pre-ossification centers of the vertebral rudiments during fetal development of the spine indicates the involvement of a KS substituted PG other than keratocan and lumican in their early development as there was no correlation in the labeling patterns of BKS-1(+) with these SLRPs. The identity of this PG is unknown; however, osteoadherin is a strong candidate as this KS SLRP is localized in bone tissue and upregulated during endochondral ossification and dentin formation [31-36]. Osteoadherin (osteomodulin) is a 49,116-Da protein containing 11 leucine-rich repeats (LRRs), 3-4 tyrosine sulfate residues at the N-terminus, and six potential glycosylation sites for $\mathrm{N}$-linked KS chains within the LRR region. Osteoadherin shows $42 \%$ sequence homology to keratocan and 37-38\% identity to fibromodulin, lumican, and PRELP [34]. Osteoadherin promotes $\alpha_{\mathrm{V}} \beta_{3}$ - integrin mediated cell binding and has been isolated as a minor, leucine and aspartic acid-rich KS-PG from mineralized tissues [36]. Osteoadherin is a relatively acidic protein which binds to hydroxyapatite and to osteoblasts through $\alpha_{\mathrm{v}} \beta_{3}$ - integrin and has been immunolocalized to pre-dentin during tooth formation [37].

The present study indicated that lumican and keratocan were prominent matrix components of the adult rat SC. These SLRPs were originally identified as bone and cartilage matrix PGs that bind and regulate growth factors such as TGF- $\beta 1$ [38] to modulate collagen fibrillogenesis. However, lumican and keratocan may also regulate SC cell populations and collagen fibrillogenesis in the developmental SC [39]. Lumican was also prominently detected as a component of the vertebral growth plate using the LUM-1 core protein antibody but was not detected using the BKS-1 MAb thus it may be present as a non-glycanated form in the growth plate. Non-glycanated forms of decorin and biglycan have previously been identified in the IVD [40,41], articular cartilage [42], and human nasal cartilage [43] however the present study is the first to identify non-GAG-substituted forms of lumican in a specific spinal tissue. An alternative possibility is that the glucosamine-6-sulfate stub epitope identified by the BKS-1 antibody is absent in some forms of lumican or access to this epitope is sterically blocked by some other group on the GAG side chain and is thus non-reactive. Non KS substituted forms of fibromodulin have been described in canine articular cartilage [44]. Non-glycanated forms of decorin and biglycan in dentine are apparently due to proteolytic removal of their N-terminal GAG substituted regions [45]. In lumican, $\mathrm{KS}$ chains are distributed at a number of sites along the core protein and are not localized at the N-terminus like in decorin and biglycan [46]. GlcNAc 6-O-sulphotransferase (Chst5) knock-out mice have been developed to ascertain the role of 6-sulphation of $\mathrm{N}$-acetyl glucosamine in KS on corneal development [47]. Lumican, the major corneal KS-PG was present as a GAG-free core protein form in the Chst5 null mouse with the corneal stroma displaying widespread structural alterations in collagen fibrillar architecture, decreased interfibrillar spacing, and general disorganization of the normal regular orthogonal arrangements of collagen fibers which are essential for corneal optical clarity [48]. The enzymatic sulfation of KS GAG chains is thus a key requirement in tissue morphogenesis and collagen matrix organization $[47,49]$. Not only is the directive role of the ECM now well appreciated in SC development [50] but its contributions to SC homeostasis in health and disease are also recognized [51] Furthermore, lumican is also an inhibitor of matrix metalloprotease (MMP)-14 and thus may regulate MMP-mediated remodeling and development of the SC ECM [52,53]. Lumcorin, a peptide derived from leucine rich repeat 9 of lumican, has cell regulatory roles via interactive properties with $\alpha 2 \beta 1$ integrin controlling cell migration and has angiostatic properties through its ability to inhibit MMP-9 and 14 and block $\alpha 2 \beta 1$ integrin interactions utilized by endothelial cells for tube formation [52,54-56]. Lumican is also a matrikine, $[57,58]$ promoting wound healing and 
tissue homeostasis by modulating physiological and pathological gene expression [57-61]. A synthetic LumC13-terminal peptide [62] YEALRVANEVTLN (Lumikine) binds ALK5/TGFBR1 (type1 TGF $\beta$ receptor) through which it promotes wound healing [61,62]. Figure 7 outlines these features in a schematic showing the structural organization of lumican and illustrates potential roles for lumican in spinal development.

Keratocan also has neuro-directory, growth factor, and morphogen interactivities supportive of SC developmental processes $[5,16,63]$. The KS chains of keratocan have interactive properties with a range of neuroregulatory proteins which direct nerve migration in neural tissues $[3,16]$. Keratocan mRNA is developmentally controlled in the anterior-posterior and dorsal ventral axes during early (E2-E3) chick embryonic development [64]. Expression of keratocan in the lateral mesenchyme is accompanied by neural cell differentiation and extension ventrally in the CNS. In the developmental cornea, accumulation of highly sulfated PGs in the posterior stroma inhibits nerve penetration; however, keratocan in the anterior epithelium is more permissive of nerve penetration [65]. Trigeminal nerve growth in the embryonic chick reaches the corneal margin by E5, and is initially repelled by highly sulfated ECM PGs encircling the corneal margins over E5-E7 entering the cornea on E7 as illustrated in Figure 7a. KS mediated Robo-Slit cell signaling also guides trigeminal nerve development and migration [66]. KS has previously been a rather neglected GAG due to an absence of known interactive ligands relevant to tissue development. However, a number of KS-interactive morphogens, growth factors, and neuroregulatory proteins have now been identified [16] reinforcing the potential importance of keratocan and lumican in spinal development. Macrophages, reactive microglia, and oligodendrocyte progenitors but not astrocytes synthesize KS-PGs following SC injury in adult Fischer 344 rats [67]. KS interacts with synaptotagmin-2 like Rho GTPase activating protein 17 (ARHGAP17) [68] and synaptotagmin a synaptic vesicle membrane protein which co-ordinates neurotransmitter release $[69,70]$. ARHGAP17, a Rho GTPase-activating protein for Rac1 also regulates CDC42 activity and remodeling of the neuronal cytoskeleton critically maintaining cellular tight junctions [71,72], formation of complexin neuronal SNARE (soluble N-ethylmaleimide sensitive factor attachment protein receptor) complexes, and the coordination of the synchronous release of synaptic neurotransmitters during neuronal activation [73]. ARHGAP17 and synaptotagmin are two examples of KS-PG interactive regulators of Rho GTPase activation and cell signaling [71-74]. Slit and Robo also interact with KS to modulate axonal development critically regulating axonal outgrowth and directional extension [75]. KS is a unique extracellular matrix (ECM) component of the roof plate which acts as a barrier to axonal development directing axonal growth in the dorsal midline [76], inhibits commissural axonal elongation through the roof plate in the embryonic SC, and provides crucial directional cues to commissural axonal development and cortical interconnections between the two brain hemispheres ensuring effective communication between the hemispheres and co-ordination of motor responses, controlling gait, balance, and posture.

In the present study, Western blotting with the KER-1 and LUM-1 antibodies alongside commercial keratocan and lumican antibodies validated both KER-1 and LUM-1 and confirmed that they detect $37 \mathrm{kDa}$ keratocan and $51 \mathrm{kDa}$ lumican core proteins in rat spinal tissues and human articular cartilage. BKS-1(+) also identified these core protein species. Higher power images of BKS-1(+) immunolocalizations in 4 month rat SC highlighted the subtlety in expression of KS on different cell types: BKS-1(+) identified positively-stained microglia throughout the grey and white matter whereas positively stained neurons were confined to the grey matter. The midline of the developing brain and SC is a place where axonal guidance decisions effects the patterning of sensory and motor systems. A variety of glial structures develop along the midline crucially directing axons to the left or right side of the CNS during spinal development [77-79]. KS has a diverse repertoire of interactive neuroregulatory ligands $[1,3,16]$, and it remains to be determined how lumican and keratocan utilize these to direct neuroregulatory processes [1,3] in SC development. Moreover, binding of KS to Shh acts as a differential regulatory switch in the transformation of motor neurons to oligodendrocytes during SC development and re-myelination during axonal repair [80] supporting novel roles for keratocan 
and lumican in such processes. It is envisaged that future discovery of lumican and keratocan ligands will serve to further reinforce their roles in neural and skeletal development.

\section{Conclusions}

BKS-1 immunolocalizations are accurate quantitative measures of KS since one BKS-1 epitope is labeled per KS chain in all KS glycoforms irrespective of their charge status whereas MAb 5-D-4 binding is multivalent and identifies highly charged hexasaccharide KS epitopes. While this improves the sensitivity of detection of KS by MAb 5-D-4, it imparts a bias towards detection of highly sulfated KS chains. BKS-1 is therefore a useful new KS antibody with significant utility in identifying KS in early tissue development in KS-PGs containing low sulfation KS glycoforms as well as highly sulfated KS in mature tissues. During fetal development, BKS-1(+) detects a yet to be identified KS-substituted PG other than keratocan and lumican within the pre-ossification centers of the vertebral bodies. MAb BKS-1 also strongly delineates KS-PGs within the inner annulus of the developing IVD. In the adult rat, BKS-1(+) expression patterns correlate closely with KS SLRPs in the SC and IVD tissue. In fetal SC and vertebral spinal tissues a close correlation is observed between BKS-1(+) and lumican, but not keratocan expression which is absent from the IVD and only weakly present in GP. The vertebral growth plate of the rat spine also appears to contain a non-glycanated form of lumican which awaits further characterization.

Author Contributions: Conceptualization, A.J.H. and J.M.; Methodology, A.J.H. and J.M.; Validation, A.J.H. and J.M.; Formal Analysis, A.J.H. and J.M.; Investigation, A.J.H. and J.M.; Resources, A.J.H. and J.M.; Data Curation, A.J.H. and J.M.; Writing-Original Draft Preparation, J.M.; Writing-Review \& Editing, A.J.H. and J.M.; Visualization, A.J.H.; Supervision, A.J.H.; Project Administration, J.M.; Funding Acquisition, A.J.H. All authors have read and agreed to the published version of the manuscript.

Funding: This study was funded by Versus Arthritis Research, UK.

Conflicts of Interest: The authors have no conflicts or financial disclosures to disclose.

\section{References}

1. Caterson, B.; Melrose, J. Keratan sulfate, a complex glycosaminoglycan with unique functional capability. Glycobiology 2018, 28, 182-206. [CrossRef] [PubMed]

2. Funderburgh, J.L. MINI REVIEW Keratan sulfate: Structure, biosynthesis, and function. Glycobiology 2000, 10, 951-958. [CrossRef] [PubMed]

3. Melrose, J. Keratan sulfate (KS)-proteoglycans and neuronal regulation in health and disease: The importance of KS -glycodynamics and interactive capability with neuroregulatory ligands. J. Neurochem. 2019, 149, 170-194. [CrossRef] [PubMed]

4. Caterson, B.; E Christner, J.; Baker, J.R. Identification of a monoclonal antibody that specifically recognizes corneal and skeletal keratan sulfate. Monoclonal antibodies to cartilage proteoglycan. J. Boil. Chem. 1983, $258,8848-8854$.

5. Gealy, E.C.; Kerr, B.C.; Young, R.D.; Tudor, D.; Hayes, A.; Hughes, C.; Caterson, B.; Quantock, A.J.; Ralphs, J.R. Differential expression of the keratan sulphate proteoglycan, keratocan, during chick corneal embryogenesis. Histochem. Cell Boil. 2007, 128, 551-555. [CrossRef]

6. Mehmet, H.; Scudder, P.; Tang, P.W.; Hounsell, E.F.; Feizi, T.; Caterson, B. The antigenic determinants recognized by three monoclonal antibodies to keratan sulphate involve sulphated hepta- or larger oligosaccharides of the poly (N-acetyllactosamine) series. JBIC J. Boil. Inorg. Chem. 1986, 157, 385-391. [CrossRef]

7. Nakao, H.; Nagai, Y.; Kojima, A.; Toyoda, H.; Kawasaki, N.; Kawasaki, T. Binding specificity of R-10G and TRA-1-60/81, and substrate specificity of keratanase II studied with chemically synthesized oligosaccharides. Glycoconj. J. 2017, 34, 789-795. [CrossRef]

8. Feizi, T.; A Childs, R.; Watanabe, K.; I Hakomori, S. Three types of blood group I specificity among monoclonal anti-I autoantibodies revealed by analogues of a branched erythrocyte glycolipid. J. Exp. Med. 1979, 149, 975-980. [CrossRef] [PubMed] 
9. Young, R.D.; Akama, T.O.; Liskova, P.; Ebenezer, N.D.; Allan, B.; Kerr, B.; Caterson, B.; Fukuda, M.N.; Quantock, A.J. Differential immunogold localisation of sulphated and unsulphated keratan sulphate proteoglycans in normal and macular dystrophy cornea using sulphation motif-specific antibodies. Histochem. Cell Boil. 2006, 127, 115-120. [CrossRef]

10. Quantock, A.J.; Young, R.D.; Akama, T.O. Structural and biochemical aspects of keratan sulphate in the cornea. Cell. Mol. Life Sci. 2009, 67, 891-906. [CrossRef]

11. Akhtar, S.; Kerr, B.C.; Hayes, A.; Hughes, C.; Meek, K.M.; Caterson, B. Immunochemical Localization of Keratan Sulfate Proteoglycans in Cornea, Sclera, and Limbus Using a Keratanase-Generated Neoepitope Monoclonal Antibody. Investig. Opthalmology Vis. Sci. 2008, 49, 2424-2431. [CrossRef] [PubMed]

12. Zhang, X.; Xia, K.; Lin, L.; Zhang, F.; Yu, Y.; Ange, K.S.; Han, X.; Edsinger, E.; Sohn, J.J.; Linhardt, R.J. Structural and Functional Components of the Skate Sensory Organ Ampullae of Lorenzini. ACS Chem. Boil. 2018, 13, 1677-1685. [CrossRef] [PubMed]

13. Josberger, E.E.; Hassanzadeh, P.; Deng, Y.; Sohn, J.; Rego, M.J.; Amemiya, C.T.; Rolandi, M. Proton conductivity in ampullae of Lorenzini jelly. Sci. Adv. 2016, 2, e1600112. [CrossRef] [PubMed]

14. Vivier, E.; Sorrell, J.M.; Ackerly, M.; Robertson, M.J.; A Rasmussen, R.; Levine, H.; Anderson, P. Developmental regulation of a mucinlike glycoprotein selectively expressed on natural killer cells. J. Exp. Med. 1993, 178, 2023-2033. [CrossRef]

15. Furukawa, J.-I.; Okada, K.; Shinohara, Y. Glycomics of human embryonic stem cells and human induced pluripotent stem cells. Glycoconj. J. 2016, 33, 707-715. [CrossRef]

16. Conrad, A.H.; Zhang, Y.; Tasheva, E.S.; Conrad, G.W. Proteomic analysis of potential keratan sulfate, chondroitin sulfate A, and hyaluronic acid molecular interactions. Investig. Opthalmology Vis. Sci. 2010, 51, 4500-4515. [CrossRef]

17. Melrose, J.; Fuller, E.S.; Roughley, P.J.; Smith, M.M.; Kerr, B.; Hughes, C.; Caterson, B.; Little, C.B. Fragmentation of decorin, biglycan, lumican and keratocan is elevated in degenerate human meniscus, knee and hip articular cartilages compared with age-matched macroscopically normal and control tissues. Arthritis Res. Ther. 2008, 10, R79. [CrossRef]

18. Hayes, A.; Isaacs, M.D.; Hughes, C.; Caterson, B.; Ralphs, J.R. Collagen fibrillogenesis in the development of the annulus fibrosus of the intervertebral disc. Eur. Cell Mater. 2011, 22, 226-241. [CrossRef]

19. Kotwal, R.; Harris, A.M.; Wright, A.E.; Hodgson, P.; Hughes, C.E.; Roberts, S.; Richardson, J.; Caterson, B.; Dent, C. Monoclonal antibodies recognising keratan sulphate (KS) proteoglycans, "KS-stubs" and KS sulphation motifs used in ELISA to quantify changes in proteoglycan metabolism in musculoskeletal diseases. J. Bone Jt. Surg. 2007, 91B, 292.

20. Okayasu, K.; Ohtani, Y.; Takemura, T.; Uchibori, K.; Tamaoka, M.; Furuiye, M.; Miyazaki, Y.; Inase, N.; Yoshizawa, Y. Nonspecific interstitial pneumonia (NSIP) associated with anti-KS antibody: Differentiation from idiopathic NSIP. Intern. Med. 2009, 48, 1301-1306. [CrossRef]

21. Yasogawa, Y.; Takano, Y.; Okayasu, I.; Kakita, A. The 5D4 antibody (anti-cyclin D1/D2) related antigen: Cytoplasmic staining is correlated to the progression of gastric cancer. Pathol. Int. 1998, 48, 717-722. [CrossRef] [PubMed]

22. Brown, S.; Melrose, J.; Caterson, B.; Roughley, P.; Eisenstein, S.M.; Roberts, S. A comparative evaluation of the small leucine-rich proteoglycans of pathological human intervertebral discs. Eur. Spine J. 2012, 21, 154-159. [CrossRef] [PubMed]

23. Melrose, J.; Smith, S.M.; Fuller, E.S.; Young, A.A.; Roughley, P.J.; Dart, A.; Little, C.B. Biglycan and fibromodulin fragmentation correlates with temporal and spatial annular remodelling in experimentally injured ovine intervertebral discs. Eur. Spine J. 2007, 16, 2193-2205. [CrossRef]

24. A Young, A.; Smith, M.M.; Smith, S.M.; A Cake, M.; Ghosh, P.; A Read, R.; Melrose, J.; Sonnabend, D.H.; Roughley, P.J.; Little, C.B. Regional assessment of articular cartilage gene expression and small proteoglycan metabolism in an animal model of osteoarthritis. Arthritis Res. Ther. 2005, 7, R852-R861. [CrossRef]

25. Rees, S.; Waggett, A.; Kerr, B.; Probert, J.; Gealy, E.; Dent, C.; Caterson, B.; Hughes, C. Immunolocalisation and expression of keratocan in tendon. Osteoarthr. Cartil. 2009, 17, 276-279. [CrossRef] [PubMed]

26. Kerr, B. Keratan sulphate metabolism in connective tissue proteoglycans. Ph.D. Thesis, Cardiff University, Cardiff, UK, 2005. 
27. Türker, E.; Garreis, F.; Khajavi, N.; Reinach, P.S.; Joshi, P.; Brockmann, T.; Lucius, A.; Ljubojevic, N.; Turan, E.; Cooper, D.; et al. Vascular Endothelial Growth Factor (VEGF) Induced Downstream Responses to Transient Receptor Potential Vanilloid 1 (TRPV1) and 3-Iodothyronamine (3-T1AM) in Human Corneal Keratocytes. Front. Endocrinol. 2018, 9, 670. [CrossRef]

28. Brosseau, J.-P.; Liao, C.-P.; Wang, Y.; Ramani, V.; Vandergriff, T.; Lee, M.; Patel, A.; Ariizumi, K.; Le, L. NF1 heterozygosity fosters de novo tumorigenesis but impairs malignant transformation. Nat. Commun. 2018, 9 , 5014. [CrossRef]

29. Jana, S.; Zhang, H.; Lopaschuk, G.D.; Freed, D.H.; Sergi, C.; Kantor, P.F.; Oudit, G.Y.; Kassiri, Z. Disparate Remodeling of the Extracellular Matrix and Proteoglycans in Failing Pediatric Versus Adult Hearts. J. Am. Hear. Assoc. 2018, 7, e010427. [CrossRef]

30. Melrose, J.; Smith, S.; Cake, M.; Read, R.; Whitelock, J. Comparative spatial and temporal localisation of perlecan, aggrecan and type I, II and IV collagen in the ovine meniscus: An ageing study. Histochem. Cell Boil. 2005, 124, 225-235. [CrossRef]

31. Nikdin, H.; Olsson, M.-L.; Hultenby, K.; Sugars, R. Osteoadherin Accumulates in the Predentin towards the Mineralization Front in the Developing Tooth. PLoS ONE 2012, 7, e31525. [CrossRef]

32. Ramstad, V.; Franzen, A.; Heinegård, D.; Wendel, M.; Reinholt, F. Ultrastructural Distribution of Osteoadherin in Rat Bone Shows a Pattern Similar to That of Bone Sialoprotein. Calcif. Tissue Int. 2003, 72, 57-64. [CrossRef]

33. Rehn, A.P.; Cerny, R.; Sugars, R.; Kaukua, N.; Wendel, M. Osteoadherin is Upregulated by Mature Osteoblasts and Enhances Their In Vitro Differentiation and Mineralization. Calcif. Tissue Int. 2008, 82, 454-464. [CrossRef] [PubMed]

34. Sommarin, Y.; Wendel, M.; Shen, Z.; Hellman, U.; Heinegård, D. Osteoadherin, a Cell-binding Keratan Sulfate Proteoglycan in Bone, Belongs to the Family of Leucine-rich Repeat Proteins of the Extracellular Matrix. J. Boil. Chem. 1998, 273, 16723-16729. [CrossRef] [PubMed]

35. Sugars, R.; Olsson, M.-L.; Marchner, S.; Hultenby, K.; Wendel, M. The glycosylation profile of osteoadherin alters during endochondral bone formation. Bone 2013, 53, 459-467. [CrossRef]

36. Wendel, M.; Sommarin, Y.; Heinegård, D. Bone Matrix Proteins: Isolation and Characterization of a Novel Cell-binding Keratan Sulfate Proteoglycan (Osteoadherin) from Bovine Bone. J. Cell Boil. 1998, 141, 839-847. [CrossRef]

37. Petersson, U.; Hultenby, K.; Wendel, M. Identification, distribution and expression of osteoadherin during tooth formation. Eur. J. Oral Sci. 2003, 111, 128-136. [CrossRef]

38. Hildebrand, A.; Romaris, M.; Rasmussen, L.M.; Heinegård, D.; Twardzik, D.R.; A Border, W.; Ruoslahti, E. Interaction of the small interstitial proteoglycans biglycan, decorin and fibromodulin with transforming growth factor $\beta$. Biochem. J. 1994, 302, 527-534. [CrossRef]

39. Chen, S.; Birk, D.E. The regulatory roles of small leucine-rich proteoglycans in extracellular matrix assembly. FEBS J. 2013, 280, 2120-2137. [CrossRef]

40. I Inkinen, R.; Lammi, M.J.; Lehmonen, S.; Puustjärvi, K.; Kääpä, E.; I Tammi, M. Relative increase of biglycan and decorin and altered chondroitin sulfate epitopes in the degenerating human intervertebral disc. J. Rheumatol. 1998, 25, 506-514.

41. Johnstone, B.; Markopoulos, M.; Neame, P.; Caterson, B. Identification and characterization of glycanated and non-glycanated forms of biglycan and decorin in the human intervertebral disc. Biochem. J. 1993, 292, 661-666. [CrossRef]

42. Roughley, P.J.; White, R.J.; Magny, M.C.; Liu, J.; Pearce, R.H.; Mort, J.S. Non-proteoglycan forms of biglycan increase with age in human articular cartilage. Biochem. J. 1993, 295, 421-426. [CrossRef] [PubMed]

43. Theocharis, A.D.; Karamanos, N.K.; Papageorgakopoulou, N.; Tsiganos, C.P.; A Theocharis, D. Isolation and characterization of matrix proteoglycans from human nasal cartilage. Compositional and structural comparison between normal and scoliotic tissues. Biochim. et Biophys. Acta. 2002, 1569, 117-126. [CrossRef]

44. Burton-Wurster, N.; Liu, W.; Matthews, G.L.; Lust, G.; Roughley, P.J.; Glant, T.T.; Cs-Szabó, G. TGF beta 1 and biglycan, decorin, and fibromodulin metabolism in canine cartilage. Osteoarthr. Cartil. 2003, 11, 167-176. [CrossRef]

45. Septier, D.; Hall, R.; Embery, G.; Goldberg, M. Immunoelectron Microscopic Visualization of Pro- and Secreted Forms of Decorin and Biglycan in the Predentin and During Dentin Formation in the Rat Incisor. Calcif. Tissue Int. 2001, 69, 38-45. [CrossRef] [PubMed] 
46. Dunlevy, J.R.; Neame, P.J.; Vergnes, J.-P.; Hassell, J.R. Identification of theN-Linked Oligosaccharide Sites in Chick Corneal Lumican and Keratocan That Receive Keratan Sulfate. J. Boil. Chem. 1998, 273, 9615-9621. [CrossRef] [PubMed]

47. Hayashida, Y.; Akama, T.O.; Beecher, N.; Lewis, P.; Young, R.D.; Meek, K.M.; Kerr, B.; Hughes, C.; Caterson, B.; Tanigami, A.; et al. Matrix morphogenesis in cornea is mediated by the modification of keratan sulfate by GlcNAc 6-O-sulfotransferase. Proc. Natl. Acad. Sci. USA 2006, 103, 13333-13338. [CrossRef]

48. Rao, W.W.-Y.; Liu, C.-Y. Roles of lumican and keratocan on corneal transparency. Glycoconj. J. 2002, 19, $275-285$.

49. Dunlevy, J.R.; Beales, M.P.; Berryhill, B.L.; Cornuet, P.K.; Hassell, J.R. Expression of the Keratan Sulfate Proteoglycans Lumican, Keratocan and Osteoglycin/Mimecan During Chick Corneal Development. Exp. Eye Res. 2000, 70, 349-362. [CrossRef]

50. Wiese, S.; Faissner, A. The role of extracellular matrix in spinal cord development. Exp. Neurol. 2015, 274, 90-99. [CrossRef]

51. Gaudet, A.; Popovich, P.G. Extracellular matrix regulation of inflammation in the healthy and injured spinal cord. Exp. Neurol. 2014, 258, 24-34. [CrossRef]

52. Pietraszek-Gremplewicz, K.; Brézillon, S.; Perreau, C.; Malicka-Błaszkiewicz, M.; Maquart, F.-X.; Wegrowski, Y. Lumican - Derived Peptides Inhibit Melanoma Cell Growth and Migration. PLoS ONE 2013, 8, e76232.

53. Pietraszek-Gremplewicz, K.; Chatron-Colliet, A.; Brézillon, S.; Perreau, C.; Jakubiak-Augustyn, A.; Krotkiewski, H.; Maquart, F.-X.; Wegrowski, Y. Lumican: A new inhibitor of matrix metalloproteinase-14 activity. FEBS Lett. 2014, 588, 4319-4324. [CrossRef]

54. Brézillon, S.; Pietraszek-Gremplewicz, K.; Maquart, F.-X.; Wegrowski, Y. Lumican effects in the control of tumour progression and their links with metalloproteinases and integrins. FEBS J. 2013, 280, 2369-2381. [CrossRef] [PubMed]

55. Stasiak, M.; Boncela, J.; Perreau, C.; Karamanou, K.; Chatron-Colliet, A.; Proult, I.; Przygodzka, P.; Chakravarti, S.; Maquart, F.-X.; Kowalska, M.A.; et al. Lumican Inhibits SNAIL-Induced Melanoma Cell Migration Specifically by Blocking MMP-14 Activity. PLoS ONE 2016, 11, e0150226. [CrossRef] [PubMed]

56. Zeltz, C.; Brézillon, S.; Perreau, C.; Ramont, L.; Maquart, F.-X.; Wegrowski, Y. Lumcorin: A leucine-rich repeat 9-derived peptide from human lumican inhibiting melanoma cell migration. FEBS Lett. 2009, 583, 3027-3032. [CrossRef] [PubMed]

57. Ricard-Blum, S.; Salza, R. Matricryptins and matrikines: Biologically active fragments of the extracellular matrix. Exp. Dermatol. 2014, 23, 457-463. [CrossRef]

58. Sivaraman, K.; Shanthi, C. Matrikines for therapeutic and biomedical applications. Life Sci. 2018, 214, 22-33. [CrossRef]

59. Maquart, F.-X.; Bellon, G.; Brassart-Pasco, S.; Monboisse, J. Matrikines in the regulation of extracellular matrix degradation. Biochim. 2005, 87,353-360. [CrossRef]

60. Ricard-Blum, S.; Vallet, S.D. Fragments generated upon extracellular matrix remodeling: Biological regulators and potential drugs. Matrix Boil. 2019, 75-76, 170-189. [CrossRef]

61. Yamanaka, O.; Yuan, Y.; Coulson-Thomas, V.J.; Gesteira, T.F.; Call, M.K.; Zhang, Y.; Zhang, J.; Chang, S.-H.; Xie, C.; Liu, C.-Y.; et al. Lumican Binds ALK5 to Promote Epithelium Wound Healing. PLoS ONE 2013, 8, e82730. [CrossRef]

62. Gesteira, T.F.; Coulson-Thomas, V.J.; Yuan, Y.; Zhang, J.; Nader, H.B.; Kao, W.W. Lumican Peptides: Rational Design Targeting ALK5/TGFBRI. Sci. Rep. 2017, 7, 42057. [CrossRef] [PubMed]

63. Weyers, A.; Yang, B.; Solakyildirim, K.; Yee, V.; Li, L.; Zhang, F.; Linhardt, R.J. Isolation of bovine corneal keratan sulfate and its growth factor and morphogen binding. FEBS J. 2013, 280, 2285-2293. [CrossRef] [PubMed]

64. Conrad, A.H.; Conrad, G.W. The keratocan gene is expressed in both ocular and non-ocular tissues during early chick development. Matrix Boil. 2003, 22, 323-337. [CrossRef]

65. Schwend, T.; Deaton, R.J.; Zhang, Y.; Caterson, B.; Conrad, G.W. Corneal Sulfated Glycosaminoglycans and Their Effects on Trigeminal Nerve Growth Cone Behavior In Vitro: Roles for ECM in Cornea Innervation. Investig. Opthalmology Vis. Sci. 2012, 53, 8118-8137. [CrossRef]

66. Schwend, T.; Lwigale, P.Y.; Conrad, G.W. Nerve repulsion by the lens and cornea during cornea innervation is dependent on Robo-Slit signaling and diminishes with neuron age. Dev. Boil. 2012, 363, 115-127. [CrossRef]

67. Jones, L.L.; Tuszynski, M.H. Spinal Cord Injury Elicits Expression of Keratan Sulfate Proteoglycans by Macrophages, Reactive Microglia, and Oligodendrocyte Progenitors. J. Neurosci. 2002, 22, 4611-4624. [CrossRef] 
68. Lee, S.-Y.; Kim, H.; Kim, K.; Lee, H.; Lee, S.; Lee, D. Arhgap17, a RhoGTPase activating protein, regulates mucosal and epithelial barrier function in the mouse colon. Sci. Rep. 2016, 6, 26923. [CrossRef]

69. Bacaj, T.; Wu, D.; Yang, X.; Morishita, W.; Zhou, P.; Xu, W.; Malenka, R.C.; Südhof, T.C. Synaptotagmin-1 and synaptotagmin-7 trigger synchronous and asynchronous phases of neurotransmitter release. Neuron 2013, 80, 947-959. [CrossRef]

70. Südhof, T.C. A molecular machine for neurotransmitter release: Synaptotagmin and beyond. Nat. Med. 2013, 19, 1227-1231. [CrossRef]

71. Richnau, N.; Aspenström, P. RICH, a Rho GTPase-activating Protein Domain-containing Protein Involved in Signaling by Cdc42 and Rac1. J. Boil. Chem. 2001, 276, 35060-35070. [CrossRef]

72. Wells, C.D.; Fawcett, J.P.; Traweger, A.; Yamanaka, Y.; Goudreault, M.; Elder, K.; Kulkarni, S.; Gish, G.; Virag, C.; Lim, C.; et al. A Rich1/Amot complex regulates the Cdc42 GTPase and apical-polarity proteins in epithelial cells. Cell 2006, 125, 535-548. [CrossRef]

73. Zhou, Q.; Zhou, P.; Wang, A.L.; Wu, D.; Zhao, M.; Südhof, T.C.; Brunger, A.T. The primed SNARE-complexinsynaptotagmin complex for neuronal exocytosis. Nat. 2017, 548, 420-425. [CrossRef]

74. Schivell, A.E.; Batchelor, R.H.; Bajjalieh, S.M. Isoform-specific, Calcium-regulated Interaction of the Synaptic Vesicle Proteins SV2 and Synaptotagmin. J. Boil. Chem. 1996, 271, 27770-27775. [CrossRef]

75. Plachez, C.; Andrews, W.; Liapi, A.; Knoell, B.; Drescher, U.; Mankoo, B.; Zhe, L.; Mambetisaeva, E.; Annan, A.; Bannister, L. Robos are required for the correct targeting of retinal ganglion cell axons in the visual pathway of the brain. Mol. Cell. Neurosci. 2008, 37, 719-730. [CrossRef]

76. Snow, D.M.; Lemmon, V.P.; Carrino, D.A.; Caplan, A.; Silver, J. Sulfated proteoglycans in astroglial barriers inhibit neurite outgrowth in vitro. Exp. Neurol. 1990, 109, 111-130. [CrossRef]

77. Kriegstein, A.R.; Alvarez-Buylla, A. The glial nature of embryonic and adult neural stem cells. Annu. Rev. Neurosci. 2009, 32, 149-184. [CrossRef]

78. Song, I.; Dityatev, A. Crosstalk between glia, extracellular matrix and neurons. Brain Res. Bull. 2018, 136, 101-108. [CrossRef]

79. Theocharidis, U.; Long, K.R.; Ffrench-Constant, C.; Faissner, A. Regulation of the neural stem cell compartment by extracellular matrix constituents. Prog. Brain Res. 2014, 214, 3-28.

80. Hashimoto, H.; Ishino, Y.; Jiang, W.; Yoshimura, T.; Takeda-Uchimura, Y.; Uchimura, K.; Kadomatsu, K.; Ikenaka, K. Keratan Sulfate Regulates the Switch from Motor Neuron to Oligodendrocyte Generation During Development of the Mouse Spinal Cord. Neurochem. Res. 2016, 41, 450-462. [CrossRef] 